\title{
THE IMPORTANCE OF STRATEGIC LEADERSHIP FOR PORT MANAGEMENT: A DELPHI RESEARCH ON TOP MANAGERS OF TURKISH PRIVATE PORTS
}

\author{
*Çagdas EMIROGLU \\ **Didem Ozer CAYLAN
}

${ }^{*}$ Atasehir District 8229/1 Street

\begin{abstract}
Ports have a key role in facilitating trade, playing a critical interface between sea and land based transportation. They are essential parts of international supply chain networks. Considering the strategic importance of ports, there is a need to evaluate strategic leadership perspectives of port management in this chain. The purpose of the study is to analyze the strategic leadership perceptions of top managers in Turkish private ports and to evaluate their main motives for giving importance to strategic leadership at port management. The study used a three-round Delphi technique to collect data. A questionnaire was conducted among 12 top managers at nine private ports in Turkey between March and August, 2014. Most of the private ports included in the sample are the members of TURKLIM (Port Operators Association of Turkey) and their major is containerized cargo. The findings presented here indicate that there is an increasing need for strategic leadership characteristics of top managers of private ports. The findings reveal that it is critical for top managers of Turkish private ports to have strategic leadership qualifications for such reasons as customer loyalty, human resource management and turnover rate, international integration of ports and volatile market conditions in shipping business.
\end{abstract}

Keywords: Port Management, Strategic Management, Strategic Leadership, Delphi Survey

\section{INTRODUCTION}

Strategic leadership is the ability to anticipate, envision, maintain flexibility, and empower others to create strategic change as necessary (Hitt et al., 2003). It can be deduced fro $m$ the definition that the management of change is, often directly linked to the role of a strategic leader (Johnson et al., 2008). Strategic leadership has a direct effect on an organization's strategic flexibility and competitive advantage through the major actions (Lear, 2012) which are associated with effective strategic leadership of (1) determining strategic direction; (2) exploiting and maintaining core competencies; (3) effectively managing human capital; (4) sustaining effective corporate culture; (5) emphasizing ethical practices; (6) establishing strategic control; and (7) investing in the development of new technologies.

Seaports as one of the most strategic points of the countries are the main scope of this study. They always play a strategic role in the development of domestic and international trade of a country. However, in a globalized world where distances are diminished, ports play an active role in sustaining the economic growth of a country (Gaur, 2005). The choice of strategies must be made by the senior managers and approved by the chief executive at port management (UNCTAD, 1993). The role of the port's chief executive can be defined as being largely concerned with government relations and strategic planning of port policies (Frankel, 1987) and also changes in the shipping market. In this context, port management needs strategic leadership qualifications of top and senior managers to manage the change.

The main aim of the study is to find out the important factors that contribute to the possession of strategic leadership qualifications of top managers in Turkish private ports and to analyze their perceptions related to strategic leadership concept. In order to reach this objective, the Delphi technique was used as a qualitative research method. The questionnaire of this technique was designed in three rounds. The paper contents the 
following sections: First section includes a literature review of strategic leadership, port management and strategic leadership in ports. The second part explains the methodology of the study, presents the findings, and finally, in the third section, the main conclusions and recommendation of the study are presented.

\section{LITERATURE REVIEW}

\section{Strategic Leadership}

The concept of strategic leadership was handled first by Hambrick and Mason (1984) in a study related to top management of organizations in 1984 (Ünal, 2012: 140). Hambrick and Mason's main theory behind strategic leadership is 'Upper Echelon Theory'. According to this theory, demographic characteristics of senior executives such as age, education and experience affect the type and level of information they use; therefore it affects strategic decisions and financial performance (Kiyak et al., 2011). Recently, considerable interest has been shown in understanding effectiveness of strategic leadership with respect to firm performance, managing organizational change, and sustaining new forms of organizational structures (Wanasika, 2009).

Strategic leadership sets the directions, meaning, purposes, and goals of the organization (Bass, 2007). According to Ireland and Hitt (1999), strategic leadership requires creating meaning and purpose for the organization with a powerful vision and mission that creates a future for the organization. Moreover, strategic leadership is the creation of an overall sense of purpose and direction (guide) integrated strategy formulation and implementation in organizations (Shrivastava and Nachman, 1989).

According to Hitt et al. (2003), strategic leadership is "the ability to anticipate, envision, maintain flexibility, and empower others to create strategic change as necessary." Strategic leadership is the influence process that facilitates the performance of the top management team to achieve objectives (Clegg et al., 2011). In addition to "influence", long-term decisions are as important as short-term decisions in the strategic leadership.

In addition to setting directions, purposes, and meaning; and ability of influence, maintaining and sustaining competitive advantage are also other vital traits of strategic leadership according to the definitions. According to Hitt and Ireland (2002) strategic leadership sets the path for firms to gain and maintain sustainable competitive advantage. Individuals and teams enact strategic leadership when they think, act, and influence in ways that promote the sustainable competitive advantage of the organization (Hughes and Beatty, 2005).

Another important point is that strategic leadership provides some fundamental characteristics in an uncertain environment. Aslan et al. (2011) focused on this point by defining strategic leadership as "the wisdom and vision capabilities of planning and implementing of the plan in an unstable, complex, uncertain strategic environment that an experienced leader should have." Strategic leader envisages, designs and realizes change by ensuring flexibility under circumstances where strategic changes are required. The most distinguishing aspect of a strategic leader is his/her ability to manage the uncertainty imposed by the rapid change (Tutar, et al., 2011). It can be deduced from definitions that strategic leadership is multifunctional, involves managing through others, and helps organizations cope with change that seems to be increasing exponentially in today's globalized business environment (Jooste and Fourie, 2009).

To compete in the global marketplace, organizations need to have strong and effective leadership (Dess and Lumpkin, 2003). According to Dess and Lumpkin (2003), there are three key leadership activities, namely setting a direction, designing the organization, and nurturing a culture committed to excellence and ethical behavior. Strategies cannot be formulated and implemented to achieve above-average returns without effective strategic leaders (Hitt et al., 2003). If executives are able to exhibit strategic leadership that achieves a long-term focus, promotes development and application of core competences, emphasizes the development of human capital, develops an effective culture, and achieves strategic control simultaneously with the allowance of autonomy, there is a higher probability that res tructuring efforts become successful (Hitt and Keats, 1992).

There are different approaches to the criteria of effective strategic leadership. Figure 1 lists those criteria:

(1) determining strategic leadership;

(2) exploiting and maintaining core competencies;

(3) effectively managing human capital; 
(4) sustaining effective corporate culture;

(5) emphasizing ethical practices;

(6) establishing strategic control; and

(7) investing in the development of new technologies.

There are also important studies on this subject which emphasized the importance of the effective role of strategic leadership (Bass, 2000; Lear, 2012; Hitt et al., 2010; Jooste and Fourie, 2009; Davies and Davies, 2004).

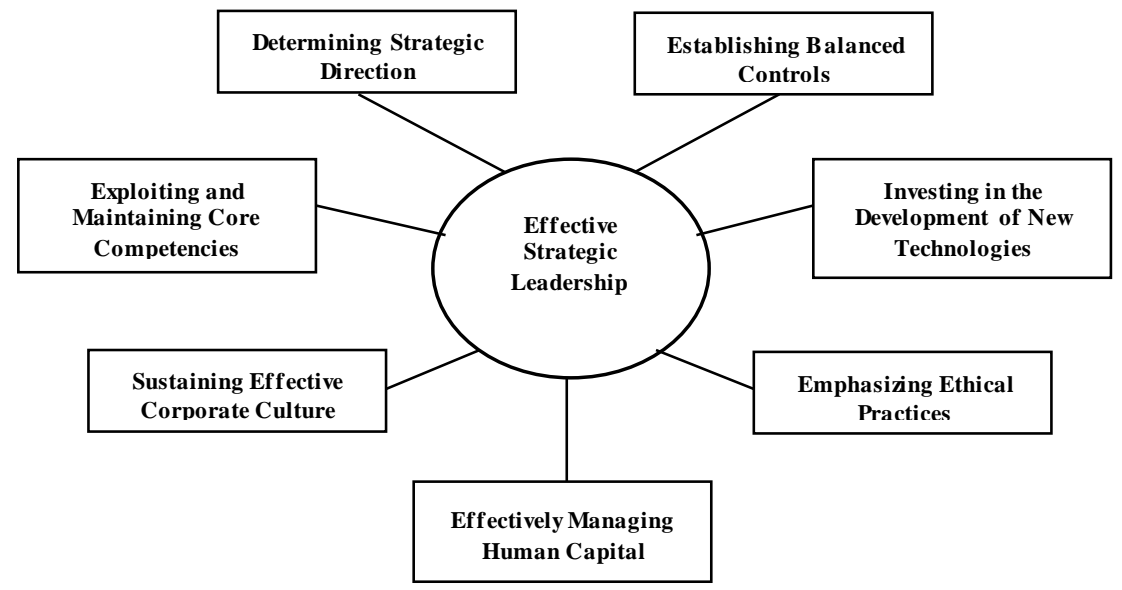

Fig 1. Criteria of Effective Strategic Leadership

\section{Port Management Functions}

Ports are very complex and dynamic places where various activities are carried out by and on account of different actors and operators; they are often dissimilar to one another (Bichou, 2010). In the past decades, the role of port management has changed quite fundamentally. The port landscape has, after all, been changed in many respects, too. New technologies and strategic developments have led almost automatically to greater port competition, both at port authority level and at the level of companies operating within the various ports (Meersman and Voorde, 2005).

Port management consists of a number of functions (Frankel, 1987):

1. Medium-to-long-term planning and strategic decision making. Th is involves also the setting or review of objectives and is performed by the top management of the port.

2. Operational planning and control, including management of day-to-day (or real-time) operations. This is performed by operating management which is concerned with traffic, operations, and engineering.

3. Co mmercial and financial control that involves marketing (real-time) accounting, short-term financial manage ment, personnel management, and other management functions involving short-term financial performance.

\section{Port Industry and Management in Turkey}

Ports have been important structures for nations since ancient times. The fact that $80 \%$ of the world trade and approximately $90 \%$ of import and export of Turkey are being transported by sea reveals the importance of ports from an economic aspect (Turkish Chamber of Shipping, 2013 and Küçükosmanoğlu et al., 2013).

Turkey has a great potential in terms of transportation with its important location as a natural bridge between Europe, Central Asia and Middle East (DPT, 2007). Additionally, Turkey is encircled by the Black Sea, the Marmara Sea, the Aegean Sea and the Mediterranean Sea. Turkey's position as a land bridge in north-south and east-west transportation means that ports are of vital importance to the efficiency of logistics operations of the country (Oral et al., 2007). Turkey's geographical location enables the ports to handle significant 
amounts of cargo between the West and the East. Cargo coming from Europe and the Americas are handled in transit to CIS Republics, Iran, Iraq, and the Balkans and vice versa. Maritime transport plays a major role at the lengthy Turkish coast, for national as well as international transportation. Turkey also has great potential in terms of intermodal transportation, owing to its privileged geographical position between European, Central Asian and Middle Eastern countries. The country's position as a land bridge in NorthSouth and East-West transportation ensures that ports play a vital role in logistic and shipping operations (Bloem et al., 2013).

387.426.232 tons of cargo was handled at Turkish ports in 2012 which had been increasing gradually since 2009. In addition, according to Turkish Chamber of Shipping (2013) $23,6 \%$ of handling is export with 91.307.486 tons; $49,7 \%$ of handling is import with 192.474 .928 tons; $12,1 \%$ of handling is cabotage with 46.919.387 tons; and 14,6\% handling is transit with 56.724.431 tons.

Turkey aims to become a center for transit cargoes in the region. The strategic position of Turkey is on increase with the pipe lines like Baku-Tiflis-Ceyhan and projects like Nabucco Gas Pipeline and South East Anatolia Project (GAP). Privatized and modernized ports will also add strength to its position (Turkish Chamber of Shipping, 2013).

In Turkey, there are more than 200 coastal facilities (port/pier/pipeline and buoy systems) providing international transportation services. Ports in Turkey can be categorized as follows (Es mer and KaratasCetin, 2013):

- Public ports (Turkish State Railways, Turkish Maritime Organizations, etc.)

- Municipal ports

- Privately owned ports (Ambarl, Gemport, etc.)

TURKLIM has industrial ports of state-owned or private companies in this categorization as members (Esmer and Karatas-Cetin, 2013). Besides, Oral et al. (2007) and Bloem et al. (2013) depicted that the ports of Turkey are classified into four groups; public ports, municipal ports, affiliated ports and privately owned ports.

According to Aksoy and Terzi (2008) and Es mer and Karatas-Cetin (2013), ports in Turkey can be analyzed in two main categories as private and public ports. While public ports comprise municipal piers, TSR (Turkish State Railways) ports and TMO (Turkish Maritime Organizations), private ports include privatized ports and ports directly established by private sector as illustrated in Figure 2.

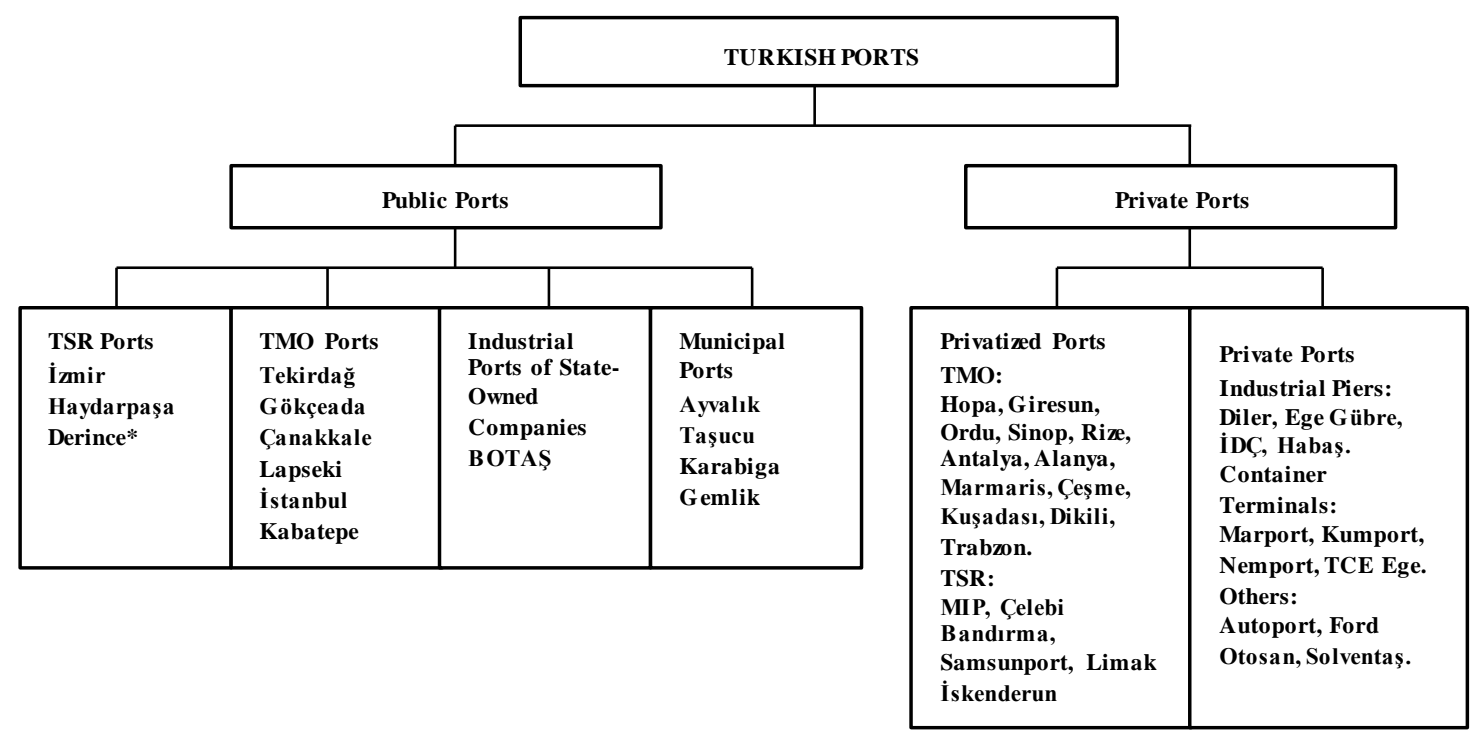

Fig.2. Classification of Turkish Ports According to Administration Models

Source: Esmer and Karatas-Cetin, 2013: 411

* Derince port has recently been privatized with the method of transfer of operational rights on $5^{\text {th }}$ June 2014 


\section{Strategic Leadership in Port Management}

Strategic leadership is the wisdom and vision capabilities of planning and implementing of a plan in an unstable, complex, uncertain strategic environment. As it is seen in the definitions, strategic leadership has a significant role for organization in environmental uncertainty (Aslan et al., 2011). Today port operations are faced with larger uncertainties and risks than ever before. These do not only include risks in cargo and therefore in ship traffic demand, but also technological risks, investment risks, risk of competition, market risk, risk in labor availability, and more (Frankel, 1987).

As mentioned before, strategic leadership is the ability to anticipate, envision, maintain flexibility, and empower others to create strategic change as necessary (Hitt et al., 2003). It can be assumed from the definition that the management of change is, however, often directly linked to the role of a strategic leader (Johnson et al., 2008). In the port system, there is a direct link between the change and effectiveness concepts. A port cannot be effective without adapting to the change in its environment (Karatas-Cetin and Cerit, 2010). In most ports, port management has found it hard to keep up with the pace of change. Furthermore, an important aspect of the legitimacy of a separate port management is being undermined, namely the previously often heard argument of the strategic significance of seaports to the economy of a country or region (Meersman and Voorde, 2005). Since the port environ ment is continually changing, various forms of restructuring can be employed at different times (UNCTAD, 1995). The important point here is how to manage change to achieve organizational effectiveness and sustain competitive advantage (Karatas-Cetin and Cerit, 2010). Strategic leadership is one of the key answers to this question.

Overall port objectives must be used to develop long-range or strategic plan for effectiveness in strategic decision making process (Frankel, 1987). Strategic leadership focuses on the way the decisions which guarantee the long-term viability of the organization are made in the short term (Lear, 2012). A port must first agree to the plan, meaning that top management must accept and be committed to the strategic planning process and its results. Without such top level support (from senior management and directors) the strategic planning process can hardly succeed (Ircha, 2001). The choice of strategies must be made by the senior managers and approved by the chief executive (UNCTAD, 1993). The role of the port's chief executive can be defined as being largely concerned with relations with the government and strategic planning of port policies (Frankel, 1987).

\section{METHODOLOGY}

\section{Purpose of the Research}

The objective of this study is to investigate importance of strategic leadership characteristics and perceptions of top managers in Turkish private ports. It is important that top managers have characteristics of strategic leadership for effective strategy implementation. Ports play a strategic role in Turkey. That's why perceptions of port top managers with regard to strategic leadership are significant to be researched.

\section{Method}

The Delphi research technique as a qualitative method is a powerful tool for strategic management. Organizations should consider the Delphi method when tackling significant decision-making that will set the future directions for organizations (Loo, 2002:762). For this reason, Delphi technique was chosen as a research method.

The preposition below is the starting point of the research and was asked to panelists in order to reach a consensus in the first round of Delphi research.

\section{Preposition: It is important that top managers have characteristics of strategic leadership in strategic management process in ports.}

Most changes in Delphi response occur in the first two rounds (Mitchell and McGoldrick, 1994: 59). On the other hand, this method may take several weeks or months to complete and tends to be administratively complex, and the investigator must try to collect, analyze, and mail the new questionnaires in an efficient and timely manner so as to maintain respondents' high level of interest and participation (Lloyd et al, 2000: 405). 
For these reasons, the three-round Delphi questionnaire has been developed and answers have been collected between March and August, 2014.

The first round Delphi survey includes one open-ended question which aims to evaluate perceptions of top managers of some private ports in Turkey concerning strategic leadership in ports. The question is designed to analyze whether possessing strategic leadership qualities is important in port management or not and, if it is, why. The second survey has been developed by using the responses of top managers, who participated in the first round Delphi survey, in order to reach a consensus. A three level likert scale including "agree", "disagree" or "no comment" has been used for each statement in the second round. The third round Delphi survey covered two questions for which no consensus was reached in the second round.

\section{Sampling and Data Collection Process}

A set of criteria were established in order to select panel members who were not only experienced in the port manage ment but also were knowledgeable in strategic management and leadership. Selection of ports was an important decision. Therefore, 24 private ports (especially container-based ones) from the member list of TURKLIM (Port Operators Association of Turkey) were chosen as the sample of the research. TURKLIM was established in order to provide cooperation and to seek solution s to the problems of the administrators of the private ports and piers in a shared platform in 1966. The association provides information flow between government and related national and international organizations like Turkish Maritime Organization. In addition, the association contributes to port managements to operate efficiently in harmony with regulations (www.turklim.org).

All questionnaires were sent by e-mail to 44 top managers with a cover letter explaining the research process individually on $14^{\text {th }}$ March, 2014. After making reminder calls, finally, 12 participants from nine private ports responded to the first round Delphi survey. The last response was received on $30^{\text {th }}$ April, 2014.

The second round Delphi survey which aimed at reaching a consensus on statements concerning strategic leadership was sent by e-mail on $26^{\text {th }}$ June, 2014 to the 12 participants who had responded to the first round Delphi survey. After reminder calls, 10 participants responded the survey. The last response received on $24^{\text {th }}$ July, 2014.

The third round Delphi survey which aimed at reaching a consensus on controversial statements in the second round was sent by e-mail on $22^{\text {th }}$ August, 2014 to the 10 participants who had responded to the second round of the Delphi survey. Seven participants responded the survey within 5 days.

Response rate was approximately $28 \%$ for the first round. Fortunately, response rate increased to roughly 84 $\%$ for the second round of the Delphi process. Finally, $70 \%$ response rate was achieved in the third round of the Delphi research.

\section{Analysis of the Delphi Survey: APMO Technique}

One of the aims of using Delphi is to achieve greater consensus among panelists. Empirically, consensus has been determined by measuring the variance in responses of Delphi panelists over rounds, with a reduction in variance being taken to indicate that greater consensus has been achieved (Rowe and Wright, 1999: 363). In order to determine if consensus has been reached, the APMO (The Average Percentage of Majority Opinion) technique which is a consensus measurement formula has been used in this study. First, the number of majority agreements and disagreements has to be calculated by expressing the participants' comments "agree", "disagree", and "no comment" in percentages per statement. Majority is actually defined as a percentage above 50\%. In the second step, the researcher has to sum up the majority agreements and disagreements. The formula \{Majority Agreements + Majority Disagreements $\div \div$ Total Opinions Expressed $\}$ has been used to calculate the APMO cut-off percentage (Von Der Gracht, 2012: 1531). 


\section{Results of the Delphi Survey and Evaluation Results of the First Round of the Delphi Survey}

The first round of the Delphi survey covers an open ended question: "In your opinion, is it important that top managers have characteristics of strategic leadership in strategic management process in ports? Why? Why not?"

Firstly, after the question is answered as "YES" (Agree) or "NO" (Disagree), the respondents are asked to explain why it is important or not. The most remarkable point here is that the answer of this yes-no question showed $100 \%$ consensus. It means that all panelists agree that it is important to have characteristics of strategic leadership in the process of strategic management in ports. Their reasons for the importance of having strategic leadership characteristics are given in Table 1.All answers are classified according to the general subjects in the table.

\section{Table 1.Answers of Panelists to the First Round Question}

\begin{tabular}{|c|c|}
\hline CATEGORIES & ANSWERS OF PANELISTS \\
\hline Position & $\begin{array}{l}\text { 1. Ports are organizations of strategic importance due to their positions. } \\
\text { 2. Ports have a strategic importance in supply chain. }\end{array}$ \\
\hline Customer & $\begin{array}{l}\text { 3. Customer orientation is fundamental for ports. } \\
\text { 4. Ports are organizations with low customer loyalty. }\end{array}$ \\
\hline Service & 5. Ports have a strategic importance with the services they provide. \\
\hline $\begin{array}{l}\text { International } \\
\text { Integration }\end{array}$ & $\begin{array}{l}\text { 6. Ports operate in an environment of extreme international integration. } \\
\text { 7. Ports have international integration so it is important that top managers should have the characteristics of strategic leader ship in } \\
\text { ports in order to make strategic decisions not only in Turkey but also globally. }\end{array}$ \\
\hline $\begin{array}{l}\text { Investment } \\
\text { decision and } \\
\text { feasibility }\end{array}$ & $\begin{array}{l}\text { 8. Ports are organizations where the initial investment decision requires detailed knowledge, documentation and calculations. } \\
\text { 9. Ports are organizations which are required to take an appropriate position in the long term. } \\
\text { 10. There is no stability in the short termin port sector; it takes time to see the results of steps. } \\
\text { 11. It is important that ports position themselves in the correct way and at the right time. } \\
\text { 12. It is important that top managers of ports guide board of directors financially and make strategic decisions in this way in order that } \\
\text { progress of port management can be healthy. } \\
\text { 13. Industries managed by strategic leaders make a difference because of the fact that their principal is to work in accordance with } \\
\text { strategic plans. }\end{array}$ \\
\hline Vision & $\begin{array}{l}\text { 14. The most important things in port management are planning the future and creating a vision. } \\
\text { 15. To predict the roles and missions of ports in the supply chain and to convince the team and shareholders by creating a vision in this } \\
\text { direction are among the most important duties of top managers in ports. }\end{array}$ \\
\hline Competition & $\begin{array}{l}\text { 16. Thanks to top managers who have strategic leadership qualifications, ports can engage in competition as well-equipped and } \\
\text { minimize the risk. }\end{array}$ \\
\hline Risk & 17. Ports are organizations which provide services in the market with high seasonal variability. \\
\hline Human Capital & 18. Ports are organizations where workers have a tendency to quit. \\
\hline $\begin{array}{l}\text { Corporate } \\
\text { Responsibi }\end{array}$ & rporate responsibility \\
\hline
\end{tabular}

Evaluation of First Round Results: Position, customer profile, services, international integration, investment decisions and feasibility, vision, competition, risk, hu man capital and corporate responsibility of ports can be considered as the main factors determining why it is important that top managers have strategic leadership characteristics in the process of strategic management in ports.

\section{Results of the Second Round of the Delphi Survey}

APMO cut-off percentage rate for the second round Delphi survey has been found as $93 \%$. In other words, if the percentage of either "agreement" or "disagreement" for each statement is greater than $93 \%$, consensus is reached. 15 statements have been developed for the second round survey by using the 19 opinions of panelists as to why it is important to have strategic leadership qualifications in the process of strategic management in ports. These 15 statements were used with the purpose of reaching a consensus on the view that characteristics of ports make possessing strategic leadership characteristics important in ports.

Evaluation of Second Round Results: Eleven statements $\left(1^{\text {st }}, 2^{\text {nd }}, 3^{\text {td }}, 4^{\text {th }}, 7^{\text {th }}, 9^{\text {th }}, 10^{\text {th }}, 11^{\text {th }}, 12^{\text {th }}, 13^{\text {th }}, 15^{\text {th }}\right)$ reached a consensus whereas $5^{\text {th }}, 6^{\text {th }}, 8^{\text {th }}$, and $14^{\text {th }}$ statements $\operatorname{did}$ not(See in Table 2). Sixth and $8^{\text {th }}$ statements reached the consensus partially because agreement percentages of those statements are very close to the 
APMO Cut-off Rate (93\%). Considering the answers of the panelists, the non-consensus statements proceed to a following Delphi round in a revised form.

\section{Results of the Third Round of the Delphi Survey}

The statements without consensus along with the answers of the panel members have been used to draw up the third round Delphi survey. APMO cut-off percentage rate for the third round Delphi survey has been found to be roughly $70 \%$. In other words, if the percentage of either "agreement" or "disagreement" for each statement is greater than $70 \%$, consensus is reached. One of the two statements has reached a consensus with the rate of 83,3\%. Other statement has not reached a consensus (See in Table 3).

Table 3.Total Results of the Third Round Delphi Survey

\begin{tabular}{|c|c|c|c|c|c|c|c|c|c|}
\hline \multirow{3}{*}{$\begin{array}{l}\text { It is important that top managers have } \\
\text { strategic leadership qualifications in the } \\
\text { process of strategic management in ports } \\
\text { B ECAUSE }\end{array}$} & \multicolumn{3}{|c|}{ Number of Answers } & \multicolumn{4}{|c|}{$\begin{array}{l}\text { Number of Opinions } \\
\text { Expressed }\end{array}$} & \multicolumn{2}{|c|}{ TOTAL RESULTS } \\
\hline & \multirow{2}{*}{$\begin{array}{c}\text { Agree } \\
\mathrm{N} \\
\end{array}$} & \multirow{2}{*}{$\begin{array}{c}\text { Disagree } \\
\mathrm{N} \\
\end{array}$} & \multirow{2}{*}{$\begin{array}{r}\text { Unable to } \\
\text { Comment } \\
\mathrm{N} \\
\end{array}$} & \multicolumn{2}{|c|}{ Agree } & \multicolumn{2}{|c|}{ Disagree } & \multirow{2}{*}{ Consensus } & \multirow{2}{*}{$\begin{array}{c}\text { Non } \\
\text { Consensus }\end{array}$} \\
\hline & & & & $\mathbf{N}$ & $\%$ & $\mathbf{N}$ & $\%$ & & \\
\hline $\begin{array}{l}\text { 5.Ports are organizations with low customer } \\
\text { loyalty. }\end{array}$ & 5 & 1 & 1 & 5 & 83,3 & 1 & 16,7 & $83,3 \%$ agreed & \\
\hline $\begin{array}{l}\text { 14. Ports are organizations where workers have a } \\
\text { tendency to quit. }\end{array}$ & 4 & 3 & 0 & 4 & 57,1 & 3 & 42,9 & & $\begin{array}{l}57,1 \%(a) \\
42,9 \%(d)\end{array}$ \\
\hline
\end{tabular}

Evaluation of Third Round Results: The majority of the panelists in the third round believe that customer loyalty is low in port business $\left(5^{\text {th }}\right.$ statement). They suggested that port managers can deal with this situation with gaining strategic leadership characteristics. One of the panelists stated that it would be hard to provide customer loyalty if there are multiple ports in the same region. There are different parameters to sustain customer loyalty. The two most important factors are price and port performance. Top managers of ports in a competitive region should make strategic decisions on price first (profitability, cost, etc.) and then port performance. They have to exhibit leadership behaviors and make decisions in order to sustain these parameters. It can be said that ports are strategic organizations and all decisions and elements should be considered strategically. Customer is one of the most significant and strategic elements for ports. Customer loyalty depends on how successfully ports are managed by top managers. For this reason ports should be managed by strategic leaders to deal with this loyalty issue.

The $14^{\text {th }}$ statement has not reached a consensus. One of the panelists depicted that turnover rates are actually low in port business. The two top-ranking factors motivating the employees are salaries and workplace environment. Any improvement in these factors decreases the turnover rate. Nonetheless, they are directly proportionate to port revenues. Any port which is making high revenue can provide the satisfaction of employees but it would be hard to provide this in small sized companies. Leadership characteristics of managers can affect employees' loyalty. However, salary policy of the port is a determinant factor. Despite the fact that managers have strategic leadership qualities, it cannot be possible to prevent the employees' decision about changing their jobs if port does not have economic power. At the same time, avoiding improvements in workplace environment because of economic reasons can be an important source of high level of turnover rates. 


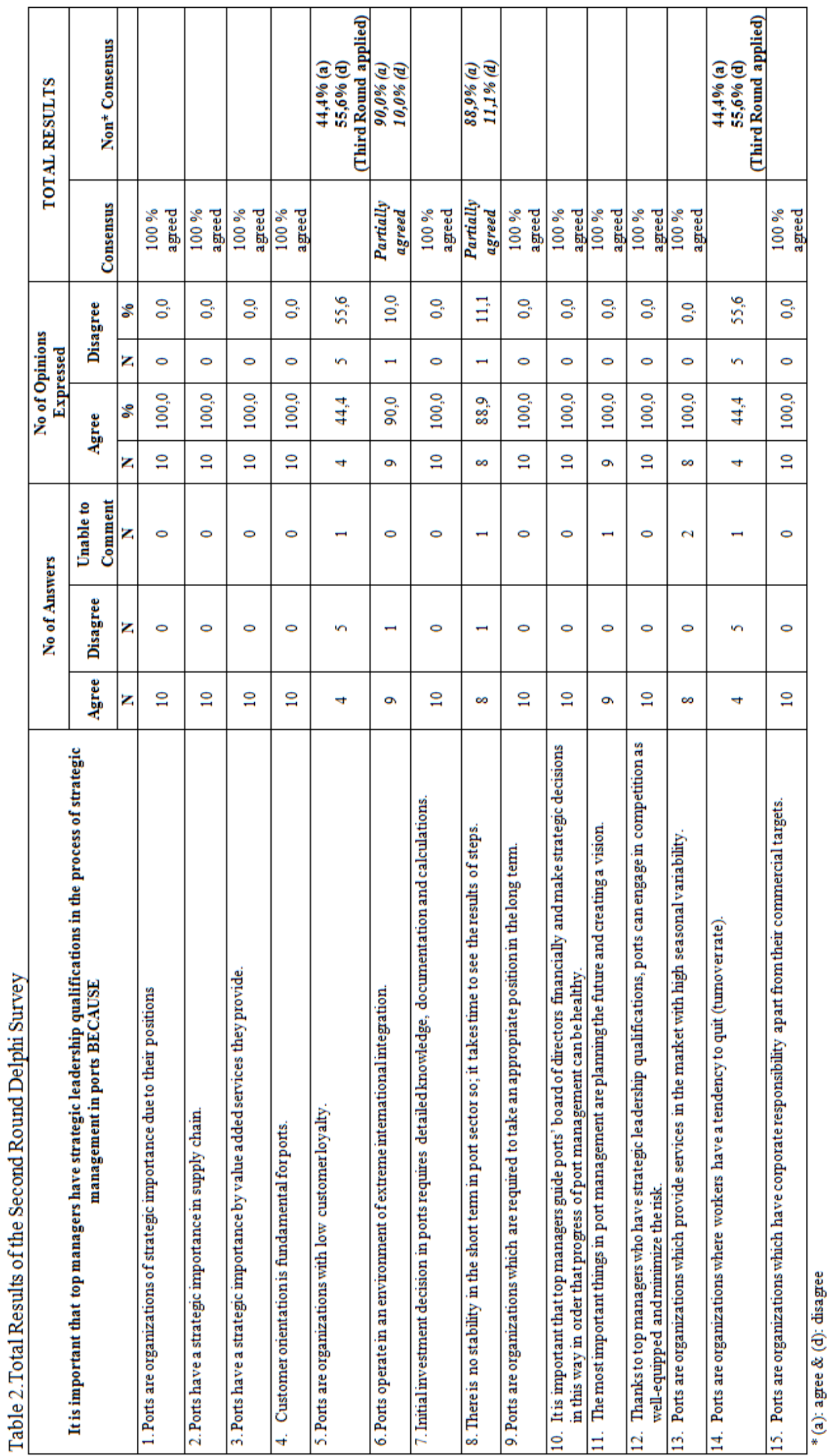




\section{CONCLUSION}

The study examined the main factors determining the importance of top managers having strategic leadership characteristics in the process of strategic management in Turkish private ports. The findings show that all the respondents totally agree that it is important to have characteristics of strategic leadership in the process of strategic management in private ports. Top managers who are responsible for administration of ports are expected to have strategic leadership qualifications because of the fact that ports have a strategic importance in the globalized world's transportation chain.

According to three-round Delphi Survey results, position of the ports, customer needs and wants, value added service, international integration, requirement of extensive investment decision, need to be visionary, excessive competition, risk factor, human capital and corporate responsibility of ports are main titles which can be considered as reasons why it is important to have strategic leadership characteristics in ports. Customers and human resources are the key elements for ports in the competitive shipping market. Therefore, the top managers as strategic leaders should pay more attention to customer relations and the causes of personnel turnover rates. In other words, ports should be managed by strategic leaders in order to be able to deal with the disloyalty of customers and human resource issues.

In order to manage an internationally-integrated port efficiently, top managers should have strategic leadership characteristics because strategic leaders can envision the direction where world trade is leading and what will be needed in the future. Therefore, ports can be affected by various macro and micro environmental factors; thus, it is difficult to maintain stability in the long term. This means that the shipping market is volatile and there is high uncertainty and risk in the port sector because of this volatility. For this reason top managers in private ports should have strategic leadership features to cope with the instability in the port sector.

The findings may reflect the general opinions of top managers of private ports about the strategic leadership; however, the authors believe that strategic leadership qualifications are also important for top managers in public ports. Further study may focus on in-depth analysis of the strategic leadership qualifications of public port managers and differences or similarities of public and private port managers in this concept.

\section{ACKNOWLEDGEMENTS}

The findings presented here are preliminary results of the authors' on-going Master of Science Thesis titled "Perceptions of Top Managers Related to Strategic Leadership: A Research on Private Ports in Turkey" at Dokuz Eylul University, Graduate School of Social Science, Maritime Business Administration MSc Program. 


\section{REFERENCES}

Aksoy, Ö.M. and Terzi, N. (2008), Liman Hizmet Terifeleri, Liman Otoritesi ve Türkiye'deki Uygulama, Konteyner Deniz ve Liman İşletmeciliği (pp. 429-447), Editor Murat Erdal, İstanbul: Beta.

Aslan, Ş., Diken, A. and Şendoğdu, A.A. (2011), Investigation of the Effects of Strategic Leadership on Strategic Change and Innovativeness of SMEs in a Perceived Environmental Uncertainty, Procedia Social and Behavioral Sciences, 24,pp.627-642.

Bass, B.M. (2000). The Future of Leadership in Learning Organizations. The Journal of Leadership Studies. 7(3): $18-40$

Bass, B.M. (2007), Executive and Strategic Leadership, International Journal Of Business, 12 (1),pp.33-52.

Bichou, K. (2009), Port Operations, Planning and Logistics, London: Informa.

Bloem, M.; Van Putten, S.; Deveci, A. and Tuna, Okan. (2013), Maritime Turkey: Market Research, Rotterdam: Strichting Nederland Maritime Land.

Clegg, S.; Carter, C., Kornberger M., and Schweitzer, J. (2011), Strategy Theory \& Practice, Los Angeles: Sage.

Davies, B.J. and Davies, B. (2004), Strategic Leadership, School Leadership \& Management, 24 (1), pp.2938.

Dess, G.G. and Lumpkin, G.T. (2003), Strategic Management: Creating Competitive Advantages, New York: McGraw-Hill.

DPT. (2007), T.C. Başbakanlık Devlet Planlama Teşkilatı, Denizyolu Ulaşımı Özel İhtisas Komisyonu Raporu, DPT-ÖIKK678, Ankara.

Esmer, S. and Karataş-Çetin, Ç. (2013), Liman İşletme Yönetimi. Denizcilik İşletmeleri Yönetimi (pp.379415), Editors A. Güldem Cerit et al. İzmir: Beta.

Frankel, E.G. (1987), Port Planning and Development, Canada: John Wiley and Sons.

Gaur, P. (2005), Port Planning as a Strategic Tool: A Typology, (Unpublished Master's Dissertation), Antwerp: Institute of Transport and Maritime Management Antwerp University of Antwerp.

Hambrick, D. and Mason, P. (1984), Upperechelons: The organization as a Reflection of its Top Managers. Academy of Management Review, 9, pp.193-206.

Hitt, M.A. and Keats, B.W. (1992), Strategic Leadership and Restructuring: A Reciprocal Interdependence, Strategic Leadership: A Multiorganizational-Level Perspective (pp.45-61), Editors Robert L. Phillips and James G. Hunt. Westport: Quorum Books.

Hitt, M.A. and Ireland, R.D. (2002), The Essence of Strategic Leadership: Managing Human and Social Capital, The Journal of Leadership and Organizational Studies, 9 (1), pp.3-14.

Hitt, M.A., Ireland, R.D., and Hoskisson, R.E. (2003), Strategic Management: Competitiveness and Globalization, 5.Edt., USA: Thomson.

Hitt, M.A., Haynes, K.T. and Serpa, R. (2010), Strategic leadership for the 21st century, Business Horizons.53,pp.437-444.

Hughes, R.L. andBeatty, K.C. (2005), Becoming a Strategic Leader: Your Role in Your Organization's Enduring Success, San Francisco: Jossey-Bass.

Ircha, M.C. (2001), Port Strategic Planning: Canadian Port Reform, Maritime Policy and Management: The Flagship Journal of International Shipping and Port Research, 28 (2), pp.125-140

Ireland, R.D. and Hitt, M.A. (1999), Achieving and Maintaining Strategic Competitiveness in the $21^{\text {st }}$ Century: The Role of Strategic Leadership, Academy of Management Executive, 13(1), pp.43-57.

Johnson, Gery; Scoles, K.; and Whittington, R. (2008), Exploring Corporate Strategy, 8.Edt., England: Prentice Hall.

Jooste, C. and Fouries B. (2009), The role of strategic leadership in effective strategy implementation: Perceptions of South African strategic leaders, Sothern African Business Review, 13 (3): 51-68. 
Meersman, H. and Voorde, E.V. (2005), Port Management, Operation and Competition: A Focus on North Europe, The Handbook of Maritime Economics and Business (pp. 765-802), Editor Costas Th. Grammenos. London: LLP.

Karatas-Cetin, .C. and Cerit, A.G. (2010), Organizational Change and Effectiveness in Seaports from a Systems Viewpoint, The Handbook of Maritime Economics and Business (pp. 947-984), Editor Costas Th. Grammenos, London: LLP.

Kıyak, M., Bozaykut, T., Güngör, P., and Akta, A. (2011), Strategic Leadership Sty les and Organizational Financial Performance: A Qualitative Study on Private Hospitals, Procedia Social and Behavioral Sciences, 24, pp.1521-1529.

Küçükosmanoğlu, Ö.;Tür, R. and Küçükosmanoğlu, A. (2013), Türkiye'deki Limanların Konumlarının Çevresel ve Ekonomik Açıdan Değerlendirilmesi, I. Ulusal Liman Kongresi Bildiriler Kitabı (pp.275-289), Editors Soner Esmer and Çimen Karataş-Çetin, İzmir.

Lear, L.W. (2012),The Relationship Between Strategic Leadership and Strategic Alignment in High-

Performing Companies in South Africa, (DoctoralDissertation), Graduate School of Business Leadership of University of South Africa.

Lloyd, J, J.M. La Lopa and C. G. Braunlich (2000). "Predicting Changes in Hong Kong's Hotel Industry Given the Change in Sovereignty from Britain to China in 1997". Journal of Travel Research, Volume 38 May, pp.405-410.

Loo, R. (2002) The Delphi Method: A Powerful Tool for Strategic Management. Policing: An International Journal of Police Strategies and Management, 25(4), pp. 762-769.

Mitchell, V.W. and P.J McGoldrick (1994). "The Role of Geodemographics in Segmenting and Targeting Consumer Markets: A Delphi Study". European Journal of Marketing, Volume 28 Number 5, pp. 54-72.

Oral, E.Z.; Kisi, H.; Cerit, A.G.; Tuna, O. and Esmer, S. (2007), Port Governance in Turkey, Research in Transportation Economics, 17, pp.171-184.

Rowe, G. and Wright, G. (1999). The Delphi Technique as a Forecasting Tool: Issues and Analysis. International Journal of Forecasting. 15: 353-375.

Shrivastava, P. and Nachman, S.A. (1989), Strategic Leadership Patterns, Strategic Management Journal, 10, pp.51-66

Tutar, H., Altınöz, M. and Çakıroğlu, D. (2011), Is ethical leadership and strategic leadership a dilemma? A descriptive survey, Procedia Social and Behavioral Sciences, 24,pp.1378-1388.

Turkish Chamber of Shipping.(2013), Maritime Sector Report 2012, Istanbul.

TURKLIM, http://www.turklim.org/ 07.09.2014

UNCTAD, (1993), Strategic Planning for Port Authorities, UNCTAD/SHIP/646.

UNCTAD.(1995), Comparative Analysis of Deregulation, Commercialization and Privatization of Ports, UNCTAD/SDD/PORT/3.

Ünal, M. (2012), Stratejik Yönetim ve Liderlik, İstanbul: Beta Basım Yayım Dağıtım.

Von der Gracht, H. A. (2012). Consensus measurement in Delphi studies:Review and Implications for Future Quality Assurance. TechnologicalForecasting \& Social Change. 79: 1525-1536.

Wanasika, I. (2009), Strategic Leadership and Rationale For Economizing-Strategizing Principles, (Doctoral Dissertation), New Mexico: Business Administration Graduate School of New Mexico State University. 